\title{
Variability of carbon dioxide flux from tropical (Cerrado) hydroelectric reservoirs
}

\author{
Fábio Roland - Luciana O. Vidal • Felipe S. Pacheco • Nathan O. Barros • Arcilan Assireu • \\ Jean P. H. B. Ometto · André C. P. Cimbleris · Jonathan J. Cole
}

Received: 30 September 2009/Accepted: 10 March 2010/Published online: 31 March 2010

(C) The Author(s) 2010. This article is published with open access at Springerlink.com

\begin{abstract}
Hydroelectric reservoirs generate energy without significant combustion of fossil fuels. However, these systems can, potentially, emit greenhouse gases (GHG's) at a rate which may be significant at the global scale, and, possible, co-equal, per kilowatt-hour, to that from conventional coal or oil-fired systems. Although much of the new construction of hydroelectric reservoirs is in the tropics, most of the data on GHG emissions comes from temperate regions. Further, much of the existing data on reservoir gas emissions comes from single sites, usually near the terminal dams. Large tropical reservoirs often involve the impoundments of river systems with complex morphology which in turn can cause spatial heterogeneity in gas flux. We evaluated spatial and seasonal variability in $\mathrm{CO}_{2}$ concentrations and gas flux for five large (50$1,400 \mathrm{~km}^{2}$ ) reservoirs in the Cerrado region of Brazil. Most of data set (87\% of all measurements) showed $\mathrm{CO}_{2}$ supersaturation and net efflux to the atmosphere. There was as much or more variation in $p \mathrm{CO}_{2}$ over space and among seasons. The large studied reservoirs showed different
\end{abstract}

F. Roland $(\bowtie) \cdot$ L. O. Vidal · F. S. Pacheco · N. O. Barros Federal University of Juiz de Fora, Juiz de Fora,

MG 36036-900, Brazil

e-mail: fabio.roland@ufjf.edu.br

A. Assireu - J. P. H. B. Ometto

National Institute of Space Research, Avenida dos Astronautas, 1758, São José dos Campos, SP 12227-010, Brazil

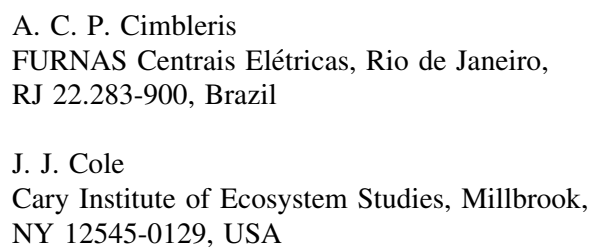

zones in terms of $\mathrm{CO}_{2}$ emission because those fluxes are dependent on flooded biomass, watershed input of organic matter and dam operation regime. Here we demonstrate that the reservoirs in the Brazilian Cerrado have low rates of $\mathrm{CO}_{2}$ emissions compared to existing global comparisons. Our results suggest that ignoring the spatial variability can lead to more than $25 \%$ error in total system gas flux.

Keywords $\mathrm{CO}_{2}$ emission - Hydroelectric reservoirs . Spatial heterogeneity $\cdot$ GHG $\cdot$ Tropical freshwaters

\section{Introduction}

The exchange of metabolic gases across the air-water interface is an important and integrative property of aquatic ecosystems and one vector of connection to their terrestrial watersheds. Aquatic systems can also be conduits for terrestrially produced $\mathrm{CO}_{2}$ from the input of high concentrations of $\mathrm{CO}_{2}$ in groundwater, as a result of soil respiration (e.g. Kling et al. 1991; Palmer et al. 2001; Jones et al. 2003). A majority of freshwater ecosystems are supersaturated in $\mathrm{CO}_{2}$, which means that these systems are a net source of $\mathrm{CO}_{2}$ to the atmosphere (Cole et al. 1994). It is known that different processes are responsible for carbon dioxide dynamics in the water column including: bacterial respiration, photooxidation (Granéli et al. 1996), surface and groundwater inflow of aqueous $\mathrm{CO}_{2}$ (alkalinity $\left(\mathrm{HCO}_{3}{ }^{-}\right.$and $\mathrm{CO}_{3}{ }^{-}$) (Stets et al. 2009); and $\mathrm{CO}_{2}$ production in sediments (Cole et al. 1994; Duarte and Prairie 2005). However, this excess $\mathrm{CO}_{2}$ is often assumed to be largely the result of respiration of allochthonous organic matter exceeding phytoplankton primary production (del Giorgio et al. 1997; Sobek et al. 2005). According to Duarte and 
Prairie (2005), the correspondence between aquatic metabolism and $\mathrm{CO}_{2}$ emissions or uptake need to be explicitly tested and not only assumed, as there are processes that may confound the relationship between aquatic metabolism and $\mathrm{CO}_{2}$ emissions.

The emission of $\mathrm{CO}_{2}$ and other greenhouse gases (GHG's) from hydroelectric reservoirs is a topic of scientific debate when considering alternative energy production. In some cases, observations suggest that the total GHG emissions from reservoirs are comparable, per kilowatt hour, to that of traditional coal or oil-fired thermoelectric production (Rudd et al. 1993; Fearnside 2004; Giles 2006). If true, hydroelectric power may not result in lowering GHG emissions. This idea has been contested (Rosa et al. 2004; Dos Santos et al. 2006). The controversy continues in part because of the paucity of studies of GHG emissions from hydroelectric reservoirs, particularly in tropical regions where there are reservoirs especially the largest ones (see Lima 2005; Guerin et al. 2006; Kemenes et al. 2007), and continue to be built (St. Louis et al. 2000).

Large impoundments may show different zones in terms of $\mathrm{CO}_{2}$ emission because those fluxes are dependent on flooded biomass, watershed input of organic matter and dam operation regime. Estimating gas emissions from larger reservoirs is complicated by the high potential for spatial variability in these fluxes. Most currently available data have not constrained this spatial variability, although the potential causes are observable. Large hydroelectric reservoirs, especially those created by impounding rivers, are morphometrically complex and quite spatially heterogeneous. Different sections of these systems inundated during their construction offer differing parts of the terrestrial landscape with vastly different amount of organic C. Further, along their lengths these reservoirs can receive new terrestrial $\mathrm{C}$ from multiple tributaries. Downriver degassing emissions can also be a significant part of gas emissions from tropical reservoirs (Abril et al. 2005, Guerin et al. 2006, 2007; Kemenes et al. 2007).

Heterotrophic and autotrophic activity plays an important role in $\mathrm{CO}_{2}$ emissions and dynamics in reservoirs. The role of both heterotrophic and autotrophic activity along reservoirs has been reported in studies of subtropical, tropical and temperate areas (Robarts and Wicks 1990; Di Siervi et al. 1995; Richardot et al. 2000; Bukaveckas et al. 2002; Raymond and Cole 2003; Lauster et al. 2006; Jugnia and Dévaux 2008; Jugnia et al. 2006; Finlay et al. 2009). While several studies focusing on gases in both the water column and sediment have been performed (Duchemin et al. 1995; Bergstrom et al. 2004; Guerin et al. 2007), few of these describe or discuss spatial variability in $\mathrm{GHG}$ fluxes. Although one would expect reservoirs to be spatially heterogeneous in their $\mathrm{CO}_{2}$ fluxes to the atmosphere, most studies on reservoir GHG emissions look at these emissions at a single site, usually close to the terminal dam.

Here, we evaluated spatial and temporal variability in $p \mathrm{CO}_{2}$ saturation for five tropical hydroelectric reservoirs in the Cerrado (Savannah) of Brazil, based on different analytical approaches. Our working hypothesis was that measurements from a single site would lead to erroneous estimates of $\mathrm{CO}_{2}$ flux from the entire surface area of the reservoirs.

\section{Methods}

\section{Hydroelectric reservoirs}

Five reservoirs are included in this study: Furnas-FNS, Mascarenhas de Moraes-MSM, Luiz Carlos Barreto de Carvalho-LBC, Manso-MAN and Funil-FUN (Fig. 1). Prior to flooding, the original vegetation type was the Cerrado biome (Savannah), which is situated on poor soils overlying pre-Cambrian rock. The climatic region is humid tropical $\left(A_{\mathrm{w}}\right.$; Niemer 1989), with a rainy season during summer and a dry period (June-August) in the austral winter. The latter season is not pronounced and average temperature for the coldest month is above $18^{\circ} \mathrm{C}$. All five reservoirs are used for the generation of electricity. They are different in age, size and hydrology (Table 1) and they are between the range mesotrophic (MAN) and slightly eutrophic (FNS, MSM).

\section{Sampling and analysis}

The partial pressure of $\mathrm{CO}_{2}\left(p \mathrm{CO}_{2}\right)$ was measured on several spatial and temporal scales on the whole body of the reservoir. This required different analytical approaches. For the spatially extensive data set, discrete samples to directly measure static $p \mathrm{CO}_{2}$ were taken during cruises that encompassed the entire length of each reservoir. The samples were taken during two seasons for FUN and MAN (rainy, March 2007; dry, August 2007). FNS, MSM and LBC were sampled only during a single dry season (August 2006). For each of the reservoirs, $p \mathrm{CO}_{2}$ samples were taken at approximately every kilometer along the length of the reservoir. For sampling at the river after the dam, only one site was sampled on the river just after the dam for MAN, FUN and LBC. FUR and MSM are connected to each other such that the output of FUR enters a river that then enters MSM. By sampling FUR near its river outlet and MSM near its river inlet, we could estimate the gas loss during the river that connects them. We had data to support this calculation on two seasons on the field campaigns dates (rainy, 21-27 March 2007 and dry, 08-25 July 2007). 
Fig. 1 Location of the studied hydroelectric reservoirs

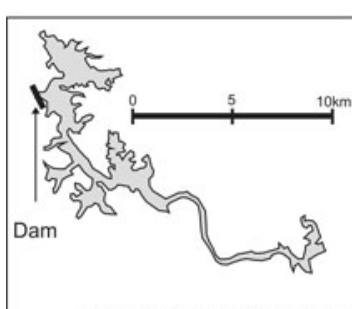

Luiz C. B de Carvalho
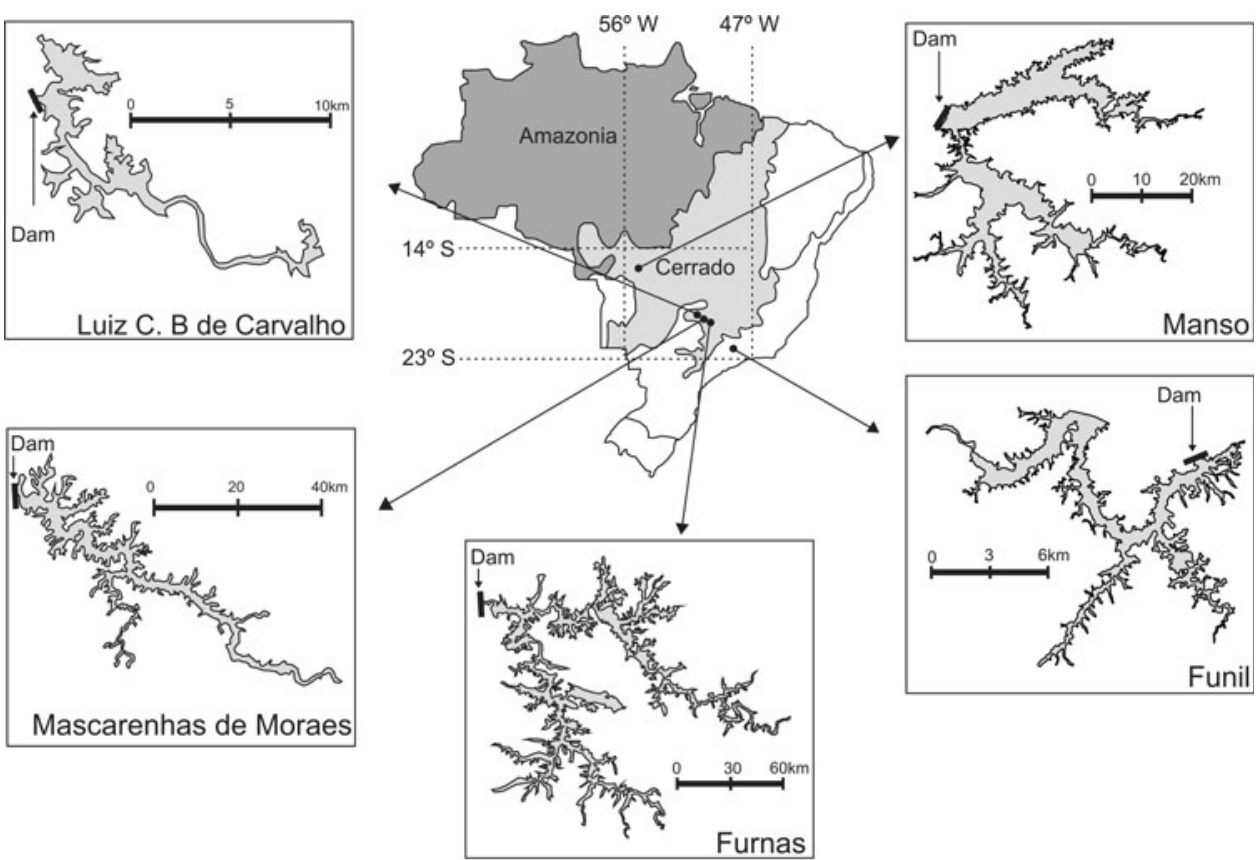

Table 1 Location and general features of the five reservoirs

\begin{tabular}{|c|c|c|c|c|c|}
\hline & \multicolumn{5}{|l|}{ Reservoirs } \\
\hline & FNS & MSM & LBC & MAN & FUN \\
\hline \multirow[t]{2}{*}{ Coordinates } & $20^{\circ} 39^{\prime} \mathrm{S}$ & $20^{\circ} 16^{\prime} \mathrm{S}$ & $20^{\circ} 09^{\prime} \mathrm{S}$ & $14^{\circ} 52^{\prime} \mathrm{S}$ & $22^{\circ} 35^{\prime} \mathrm{S}$ \\
\hline & $46^{\circ} 18^{\prime} \mathrm{W}$ & $47^{\circ} 03^{\prime} \mathrm{W}$ & $47^{\circ} 16^{\prime} \mathrm{W}$ & $55^{\circ} 46^{\prime} \mathrm{W}$ & $44^{\circ} 35^{\prime} \mathrm{W}$ \\
\hline Year of operation & 1963 & 1957 & 1969 & 2000 & 1969 \\
\hline Generate electricity (Mega Watt) & 1,216 & 476 & 1,050 & 210 & 180 \\
\hline Main river & Grande & Grande & Grande & Manso & Paraíba do Sul \\
\hline Maximum depth (m) & 89 & 43 & 55 & 40 & 45 \\
\hline Mean depth (m) & 15 & 15 & 29 & 19 & 20 \\
\hline Area $\left(\mathrm{km}^{2}\right)$ & 1,342 & 250 & 45 & 360 & 27 \\
\hline Volume $\left(\mathrm{km}^{3}\right)$ & 20.7 & 3.8 & 1.3 & 6.5 & 0.5 \\
\hline Watershed area $\left(\mathrm{km}^{2}\right)$ & 51,773 & 59,355 & 60,897 & 9,365 & 16,680 \\
\hline Organic carbon-soil $\left(\mathrm{kg} \mathrm{C} \mathrm{m}^{-2}\right)^{\mathrm{a}}$ & 4.3 & 5.3 & 4.7 & 5.3 & 4.7 \\
\hline Hydrological rivers input $\left(\mathrm{m}^{3} \mathrm{~s}^{-1}\right)$ & 780 & 969.3 & 938.9 & 192.6 & 204.8 \\
\hline Residence time (years) & 1.38 & 0.14 & 0.05 & 2.47 & 0.09 \\
\hline Outlet position & Epilimnion & Metalimnion & Metalimnion & Epilimnion & Epilimnion \\
\hline Elevation (m) & 755 & 673 & 638 & 388 & 470 \\
\hline Annual mean air tempertaure $\left({ }^{\circ} \mathrm{C}\right)$ & 20.2 & 21.6 & 22.5 & 25.3 & 18.4 \\
\hline Annual precipitation (mm) & 1,126 & 1,525 & 1,455 & 1,241 & 1,337 \\
\hline
\end{tabular}

Area and volume correspond to the respective year of study; maximum depth is average among seasons at the station nearest to the dam; residence time is daily average during the sampling month. Year of operation is the first year that power was generated

FNS Furnas, MSM Mascarenhas de Moraes, LBC Luiz Carlos Barreto de Carvalho, MAN-R Manso rainy season, MAN-D Manso dry season, $F U N-R$ Funil rainy season, FUN-D Funil dry season

a Average from the watershed soil

Concomitant with the $\mathrm{CO}_{2}$ work, samples for other water chemistry measures (alkalinity, temperature and $\mathrm{pH}$ ) were taken using a polyethylene bottle. The water for $p \mathrm{CO}_{2}$ measurements was taken at $0.5-\mathrm{m}$ depth between 8:00 and
12:00 a.m. Measurements of $p \mathrm{CO}_{2}$ was made directly using the headspace equilibrium method (Hesslein et al. 1991; Cole et al. 1994). Fifteen $\mathrm{mL}$ atmospheric air was equilibrated with $20 \mathrm{~mL}$ reservoir water by vigorous 
shaking for $1 \mathrm{~min}$ (Cole and Caraco 1998). The headspace gas was transferred to a plastic syringe, and the concentration of $\mathrm{CO}_{2}$ in the headspace gas was immediately measured using an infrared gas analyzer (IRGA-environmental gas monitor EGM-4; PP Systems). Three complete replicates for each sampling site were taken (e.g., three separate equilibrations). To evaluate the degree of humidity interference on IRGA measurements, we compared ambient (humid) air to air dried by passing it through a drying tube filled with indicating drierite, as suggested by the IRGA Operations Manual (EGM-4; PP Systems). Using 25 measurements, no significant difference was found comparing measurements with and without the drying tube $(t=2.3, P>0.05 ; n=25)$.

For the time-intensive data set, a 15 day interval, $p \mathrm{CO}_{2}$ was calculated from continuous, hourly values of $\mathrm{pH}$ and temperature and daily measurements of alkalinity (ANC) at a single site near the dam in each reservoir. These sites are instrumented with a "smart buoy" called SIMA (Environmental Integrated Monitoring System) which collects, stores and transmits key hydrogeochemical data for the reservoirs, including water and air temperature and wind speed, and detailed temperature profiles (http://www.dpi. inpe.br/sima/bancos/index.php). The SIMA buoy supports thermistor chains with 4 thermistors over a depth of 35 meters with temperature recorded every $60 \mathrm{~s}$. Additional data for $\mathrm{pH}$ and surface temperature were obtained by attaching a sonde (YSI model 6920), and exchanging and calibrating it every 15 days according YSI Environmental Operations Manual (http://www.ysi.com/ysi/support). We use standard solutions ( $\mathrm{pH} \mathrm{4,} \mathrm{7,} \mathrm{and} \mathrm{10)} \mathrm{to} \mathrm{calibrate} \mathrm{each}$ $\mathrm{pH}$ sensor. Alkalinity (ANC) was also measured by titration using $0.01 \mathrm{~N}$ sulfuric acid whenever we sampled for IRGA measurements. Besides the daily measurements (time-intensive data set), we measured ANC at every single site spatially distributed across the $p \mathrm{CO}_{2}$-IRGA measurements. This generated 462 direct measurements of ANC or an average of 39 (FUN) to 86 (MAN-R) in each reservoir depending of reservoir area. Because the spatial variation in ANC was small $(\mathrm{CV}=0.76-1.24)$, we assumed that the short-term temporal variation was also small. We calculated $p \mathrm{CO}_{2}$ from $\mathrm{ANC}, \mathrm{pH}$, and temperature according to Stumm and Morgan (1996). Water samples for measurements of total organic carbon (TOC) were analysed using a Carbon Analyzer (Phoenix 8000), where the total dissolved organic carbon was measured as $\mathrm{CO}_{2}$, following high temperature oxidation with a UV lamp. Before TOC analysis, inorganic carbon was eliminated from the samples by phosphoric acid addition and sparging for 6 min with $\mathrm{N}_{2}$-free air. At least three measurements of TOC were made for each sample; the coefficient of variation (CV) was considered acceptable when $<2 \%$.
For both the spatially and temporally intensive data sets, values of $p \mathrm{CO}_{2}$ in equilibrium with the atmosphere were calculated according to Cole et al. (1994), using Henry's law and the equations in Weiss (1974). The exchange of $\mathrm{CO}_{2}$ with the atmosphere depends of $\mathrm{CO}_{2}$ concentration in the water $\left(\mathrm{CO}_{2} \mathrm{aq}\right)$. The concentration in the water would be in equilibrium with the atmosphere $\left(\mathrm{CO}_{2}\right.$ sat $)$ and the physical rate of exchange $(k)$. The equilibrium with the atmosphere was assumed to be $365 \mu \mathrm{atm}$ (Sobek et al. 2006). In Eq. $1, k$ is the gas evasion coefficient and is dependent on wind speed according to the following equation, normalized to Schmidt number of 600 (Cole and Caraco 1998). The gas transfer velocity was calculated based on the same wind speed used to calculate fluxes.

$\mathrm{CO}_{2}$ Flux $=k \alpha\left(p \mathrm{CO}_{2}\right.$ aq $\times k h-p \mathrm{CO}_{2}$ sat $)$

$k_{600}=2.07+0.21 \mathrm{U}_{10}^{1.7}$

In Eq. 2, $\mathrm{U}_{10}$ is wind speed at 10-m height and $k_{600}$ is the piston velocity in $\mathrm{cm} \mathrm{h}^{-1}$ for a gas with a Schmidt number of 600 (Jahne et al. 1987). The daily average wind speed was obtained at SIMA at 3-m height and was calculated to $10-\mathrm{m}$ height during the investigation period and was used in all flux calculations between air and water (Smith 1985). The chemical enhancement factor, $\alpha$, was calculated from $k$ and pH according to Wanninkhof and Knox (1996).

\section{Spatial data analysis and statistical procedures}

In order to evaluate the spatial variability on the $p \mathrm{CO}_{2}$, a spatial model was applied for each reservoir. Modeling the spatial structures was carried out through variogram analysis. Variograms are the key function in geostatistical analysis used both to describe the spatial correlation among samples of a variable acquired in different locations and to spatially interpolate them using kriging (Bailey and Gatrell 1995). An empirical variogram is used as a first estimate of the (theoretical) variogram. In the study, the empirical variograms were fitted to different mathematical models using Akaike's information criterion (AIC, Akaike 1974) to evaluate the best fit. The parameters extracted from the best fitted model were used to facilitate interpolation by ordinary kriging. We used the Ordinary Kriging to produce the in situ $p \mathrm{CO}_{2}$ map. The sampling pattern was highly dense (approximately $1 \times 1 \mathrm{~km}$ ) which minimizes the uncertainty of the interpolation. Moreover, a cross test was made to evaluate the reliability of the maps. This cross-validation removes each measured point per turn, predicts a value for that location based on the rest of the data, and compares the measured and predicted values. The made interpolation based on this modeling grid was robust enough to validate the maps. This map enables the visualization of spatially distributed $p \mathrm{CO}_{2}$. The mean standardizing error was low $(<0.02)$ for all reservoirs. 
In support of more detailed studies of mixing events in MAN, we needed a bathymetric map. A Triangulated Irregular Network (TIN) was used to the level curves interpolation in order to generate the declivity along the longitudinal axis of MAN reservoir. Every $0.5 \mathrm{~km}$ from the entrance of the Manso river on the reservoir until the dam zone, the depth was measured using an echobathimetry (GPSMAP 520s Garmin). For each reservoir, a shoreline development index (SDI) was calculated in accordance with Wetzel and Likens (2000). Data to calculate the SDI (area and perimeter of the reservoir) came from Environmental Department of Furnas Centrais Elétricas S. A. (http:// www.dsr.inpe.br/projetofurnas/). It describes the roundness of a lake or the degree of dissectedness of the shore line. Lakes with values near 1 are circular and have little shoreline development.

For statistical procedures, t-tests were used to detect significant differences between $p \mathrm{CO}_{2}$ measured by sonde and by IRGA. Linear regression was used to test the degree of spatial variability among reservoirs in relation to different parameters and to check the tendency between sonde and IRGA data. Statistical analyses were performed using the software JMP (Version 5.0.1). For all statistical tests, we assumed $P<0.05$ as a threshold level for acceptance.

\section{Results}

Spatial and temporal variability in $p \mathrm{CO}_{2}$

Among reservoirs, partial pressure of $\mathrm{CO}_{2}$ measurements varied widely from 291 to $3,079 \mu$ atm (from about half to 8 times higher than atmospheric equilibrium value). In the reservoirs where seasonal variation was measured (MAN and FUN), there was an increase in $p \mathrm{CO}_{2}$ levels during the dry season. The $p \mathrm{CO}_{2}$ varied from 291 to $3,079 \mu$ atm in the rainy season and 708 to $2,837 \mu$ atm in the dry season at MAN reservoir and from 295 to $1,155 \mu$ atm in the rainy season and 394 to $1,508 \mu$ atm in the dry season at FUN reservoir. There was no significant difference between seasons $(t=1.9, P>0.05)$ in either Manso and Funil reservoirs, if we consider the full spatial data. However, we found higher values in the dry season for both systems, if we compare zones with higher values of $\mathrm{CCO}_{2}(t=2.2$, $P<0.05)$. We also found the same pattern comparing data from the dam zone $(t=2.1, P<0.05)$. The river post dam $p \mathrm{CO}_{2}$ were generally higher and varied from 865 (MSM) to 3,079 $\mu$ atm (MAN-R).

In addition, $p \mathrm{CO}_{2}$ varied spatially within each reservoir (Fig. 2). In general, the areas close to the riverine inflow
Fig. 2 Partial pressure of $\mathrm{CO}_{2}$ $\left(p \mathrm{CO}_{2} ; \mu \mathrm{atm}\right)$ in a spatial scale expressed by a color gradient obtained from an interpolation of measured data using the Ordinary Kriging statistical procedures (see text). The gray gradient represents the scattering from undersaturation (lightest gray) to supersaturation (darkest gray)

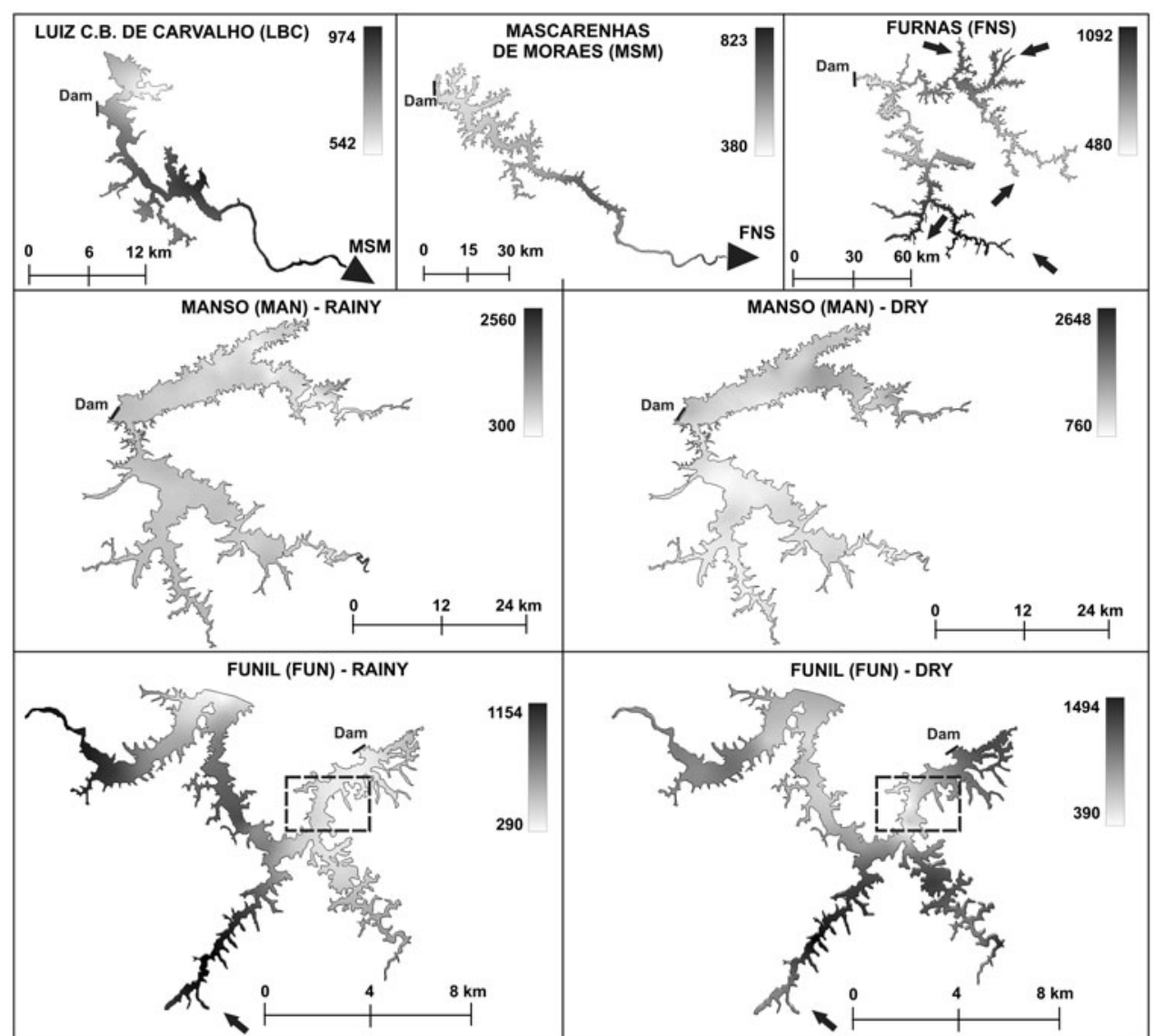


Table 2 Data of coefficient of variation of $p \mathrm{CO}_{2}$, fluxes of $\mathrm{CO}_{2}$ (IRGA, mmol m${ }^{-2} \mathrm{day}^{-1}$ ), fluxes of $\mathrm{CO}_{2}$ (probes, mmol m${ }^{-2} \mathrm{day}^{-1}$ ), TOC-tributaries (means, $\mathrm{mgC} \mathrm{L}^{-1}$ ), TOC-reservoir before dam (means, $\mathrm{mgC} \mathrm{L}^{-1}$ ), watershed area:reservoirs area ratio, Shoreline

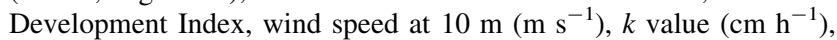
total alkalinity $\left(\mu \mathrm{Eq} \mathrm{L}{ }^{-1}\right)$, temperature $\left({ }^{\circ} \mathrm{C}\right)$

\begin{tabular}{|c|c|c|c|c|c|c|c|}
\hline & \multicolumn{7}{|l|}{ Reservoirs } \\
\hline & FNS & MSM & LBC & MAN-R & MAN-D & FUN-R & FUN-D \\
\hline Coefficient of variation of $p \mathrm{CO}_{2}$ & 0.22 & 0.29 & 0.13 & 0.46 & 0.40 & 0.37 & 0.35 \\
\hline Fluxes of $\mathrm{CO}_{2}\left(\right.$ IRGA; mmol m${ }^{-2}$ day $\left.^{-1}\right)$ & 9 & 13 & 23 & 8 & 33 & 10 & 11 \\
\hline Fluxes of $\mathrm{CO}_{2}$ (Probes; mmol m${ }^{-2}$ day $^{-1}$ ) & 12 & 38 & 64 & 72 & 105 & -130 & -136 \\
\hline TOC-tributaries (mean; $\mathrm{mgC} \mathrm{L}^{-1}$ ) & 3.1 & 2.2 & 2.2 & 2.2 & 2.9 & 4.4 & 3.9 \\
\hline TOC-reservoir before dam (mean; $\mathrm{mgC} \mathrm{L}^{-1}$ ) & 1.3 & 1.5 & 1.5 & 1.5 & 2.6 & 4.0 & 2.5 \\
\hline Watershed area:reservoir area ratio & 39 & 237 & 1353 & 26 & 26 & 627 & 627.0677 \\
\hline Shoreline development index & 20 & 9 & 8 & 9 & 9 & 13 & 12.68943 \\
\hline Wind speed at $10 \mathrm{~m}\left(\mathrm{~m} \mathrm{~s}^{-1}\right)$ & 2.99 & 3.73 & 4.87 & 2.29 & 4.68 & 2.33 & 2.86 \\
\hline$K$ value $\left(\mathrm{cm} \mathrm{h}^{-1}\right)$ & $3.5-3.6$ & $4.3-4.5$ & $5.5-5.7$ & 3.1 & $5.2-5.8$ & $3.3-3.8$ & 3.4 \\
\hline Total alkalinity $\left(\mu \mathrm{Eq} \mathrm{L}{ }^{-1}\right)$ & $206-282$ & $243-257$ & $243-254$ & $196-402$ & $231-377$ & $344-405$ & 313-394 \\
\hline Temperature $\left({ }^{\circ} \mathrm{C}\right)$ & $20.8-21.9$ & $21.9-23.4$ & $22.07-22.6$ & $27-31$ & $23-24.5$ & $26-29$ & $20.5-21$ \\
\hline
\end{tabular}

See "Methods"

had higher levels of $p \mathrm{CO}_{2}$ than the main body of the reservoir. We observed decreasing $p \mathrm{CO}_{2}$ towards the dam and increasing values downriver of the dam for all the systems. Based on the coefficient of variation (CV) of $p \mathrm{CO}_{2}$ for each reservoir, there was a wide range in variability. The CV's for spatial data sets varied between 0.13 (LBC reservoir) and 0.46 (MSM-R reservoir). However, there was about equal ranges of variability temporally to the MAN and FUN reservoirs (Table 2).

The $p \mathrm{CO}_{2}$ spatial variability changed as a result of physical event associated to water vertical mixing movement from the bottom to the surface. The mixing event was identified by examining the temperature profiles and meteorological parameters from the SIMA site (Fig. 4a, b). From the temperature isopleths (Fig. 4b), mixing occurred to a depth of $23 \mathrm{~m}$. The mixing event appeared to follow a series of strong winds (Fig. 4a, b). Peaks of rain and, especially sudden increases in wind speed (Fig. 4a; arrows) show conditions to promote mixing of the water column (Fig. 4b). From end of April to July, seven cold fronts reached Manso Reservoir (arrows in Fig. 4b). Further details about the action of cold front in Manso Reservoir can be found in Lorenzzetti et al. (2005). After the event, the zone close to the dam became much more supersaturated than before (Fig. 3a, b). The spatial distribution of $p \mathrm{CO}_{2}$ in MAN reservoir was negatively correlated with maximum depth in each section of the reservoir (Fig. 3c). Figure $3 \mathrm{c}$ shows $p \mathrm{CO}_{2}$ measurements plotted across a depth gradient in a moment without evidence of any mixing in the whole reservoir water column. Each peak in wind speed was associated with a steep fall of air temperature during the cold front passage. Air temperatures declined about $6^{\circ} \mathrm{C}$ during these events and daily average wind reached $6 \mathrm{~m} \mathrm{~s}^{-1}$. Thus, the deepening of the surface mixing layer due to the stirring from the wind stress will be enhanced by downward convective mixing in dry seasons.

The degree of spatial variability among reservoirs was correlated with several features of the systems and not with others (Fig. 5). Neither the index of shoreline development nor reservoir area explained more than $3 \%$ of the variability in the coefficients of variation of $p \mathrm{CO}_{2}$ (Fig. 5a, b). However, three characteristics (residence time per unit reservoir area; watershed area; and TOC input per unit watershed area, each explained a large fraction (69-78\%; and all significant at $P<0.05)$ of this variability (Fig. $5 \mathrm{c}, \mathrm{d}, \mathrm{e}$ ). The tributaries showed higher TOC concentration compared to the concentrations found in the reservoir before the dam (Table 2). The values varied from 2.2 to $4.4 \mathrm{mgC} \mathrm{L}^{-1}$ in tributaries and from 1.3 to $4.0 \mathrm{mgC} \mathrm{L}^{-1}$ in the reservoir before the dam. The watershed area:reservoir area ratio varied from 26 to 1,353 and the shoreline development index from 8 to 20 .

Time-intensive temporal data set of $p \mathrm{CO}_{2}$

The temporal $p \mathrm{CO}_{2}$ measured by multi-parameter sonde (temperature and $\mathrm{pH}$ ) and alkalinity showed that there is also wide seasonal variability in the sampled reservoirs. The $p \mathrm{CO}_{2}$ varied between 344 and 1,177 $\mu$ atm (Fig. 6). LBC and MAN were prevalent on $p \mathrm{CO}_{2}$ supersaturation, while FNS and FUN-dry were prevalent on $p \mathrm{CO}_{2}$ undersaturation. Considering all the temporal data across all 

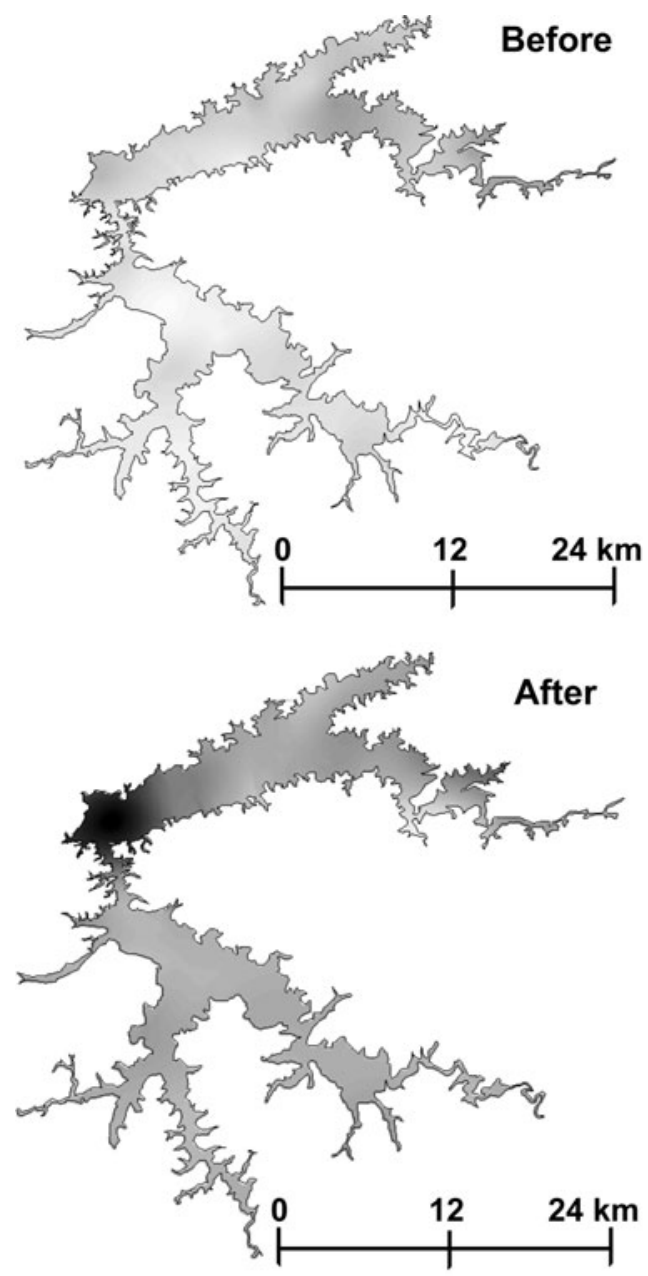

(b)

2648

760

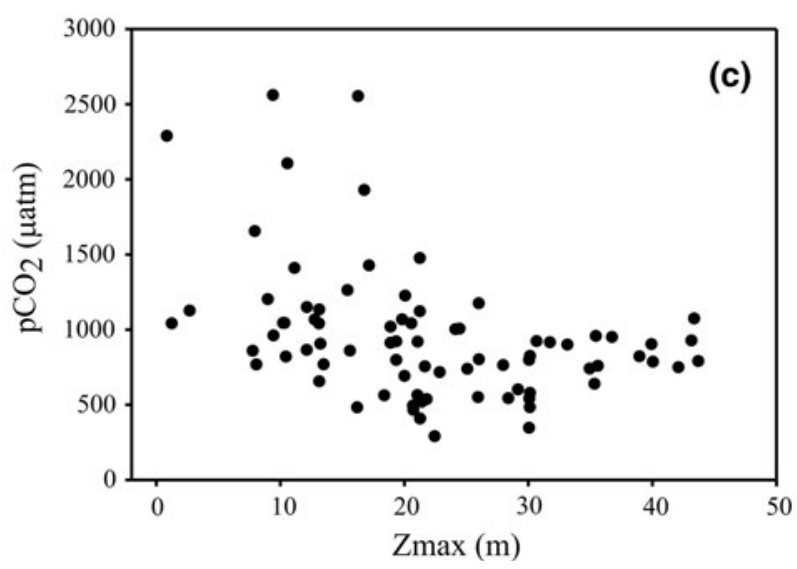

Fig. $3 p \mathrm{CO}_{2}$ data ( $\left.\mu \mathrm{atm}\right)$ in Manso reservoirs during the dry season. Spatial distribution of $p \mathrm{CO}_{2}$ before (a) and after a mixing event (b). The gray gradient on both panels represents the magnitude of $p \mathrm{CO}_{2}$ data using the Ordinary Kriging statistical procedures (see text). $p \mathrm{CO}_{2}$ measurements plotted across a depth $\left(Z_{\max }\right)$ gradient in a moment without evidence of any mixing in the whole reservoir water column (c)

5 reservoirs, daily data sets, $84.2 \%$ of the daily means were above the atmospheric equilibrium, $13.7 \%$ were below atmospheric saturation, and the remaining $2.1 \%$ were within $5 \%$ of atmospheric equilibrium.
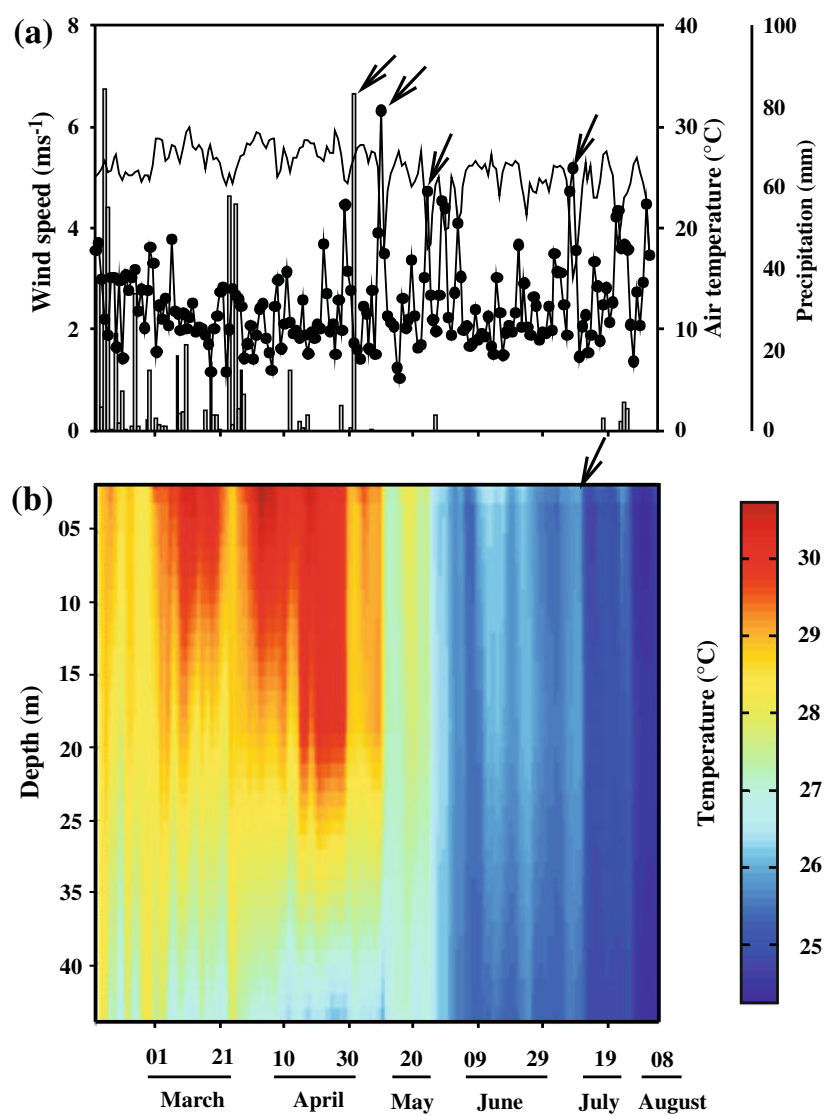

Fig. 4 Climatological data (upper panel) showing air temperature $\left({ }^{\circ} \mathrm{C}\right.$; lines $)$, wind speed $\left(\mathrm{m} \mathrm{s}^{-1}\right.$; dotted lines $)$ and precipitation $(\mathrm{mm}$; bars). The bottom panel shows the daily water temperature profiles on the water column. Data were observed between the end of the rainy season (March) and dry season (July) at Manso reservoir

High temporal frequency versus spatial variability

The $p \mathrm{CO}_{2}$ was estimated using either the sonde at SIMA sites (calculated) and IRGA (direct) present were significantly different (Fig. 7, $t$ test $=1.96, P<0.05$ ). However, the tendency between sonde and IRGA data shows that they are well correlated $\left(r^{2}=0.73, P<0.05\right)$. In general, the sonde-based data were more variable than IRGA data, and overestimated $p \mathrm{CO}_{2}$ up to $65 \%$ on average compared to the IRGA (Table 2). This is likely caused by small error in the $\mathrm{pH}$ probes measurements or calibration which have a strong effect on calculated $p \mathrm{CO}_{2}$ (Herczeg and Hesslein 1984).

\section{Discussion}

Several studies of hydroelectric reservoirs have suggested that these systems may add significant $\mathrm{CO}_{2}$ and $\mathrm{CH}_{4}$ to the atmosphere at a global scale (Rudd et al. 1993; St. Louis et al. 2000; Tremblay et al. 2004; Roehm and Tremblay 2006), and have expressed concern about the rapid rate of 

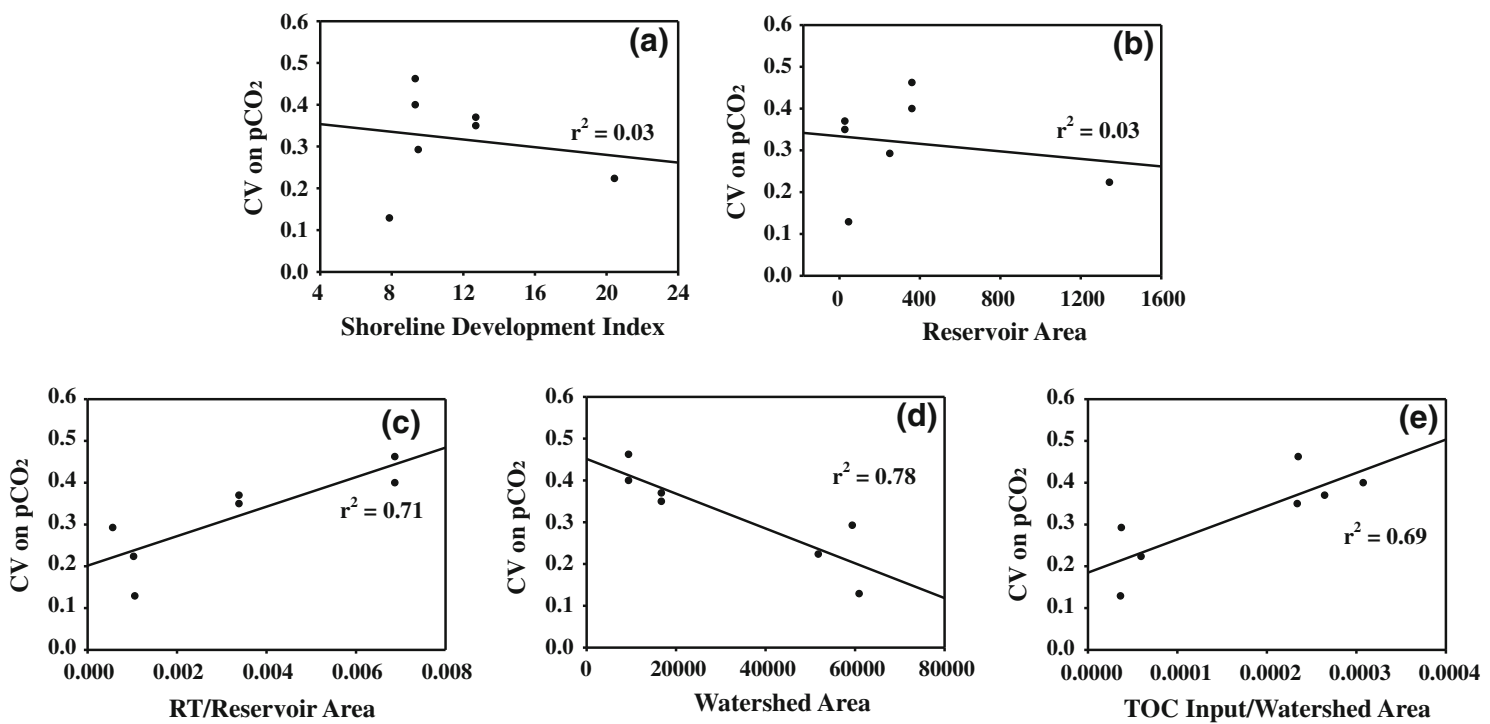

Fig. 5 Regression results describing simple relationships between coefficient of variation (CV) of $p \mathrm{CO}_{2}$ versus Shoreline Development Index (a); $\mathrm{CV}$ on $p \mathrm{CO}_{2}$ versus reservoir area (b); $\mathrm{CV}$ on $p \mathrm{CO}_{2}$ versus

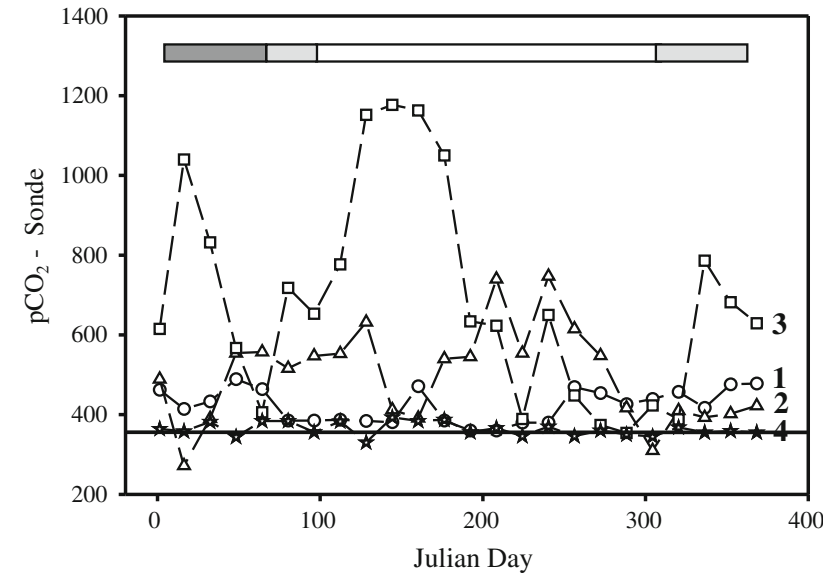

Fig. 6 Temporal series of $p \mathrm{CO}_{2}(\mu \mathrm{atm})$ for four reservoirs: Furnas (1; circle); Luiz C. B. de Carvalho (2, triangle), Manso (3; square) and Funil (4; star). The line represents the atmospheric equilibrium (365 $\mu \mathrm{atm})$. The upper bar indicates the intense rainy (dark gray), discrete rainy (gray) and dry (empty) seasons

construction of new dams, especially in the tropics. Our study shows that reservoirs in the tropical Cerrado region of Brazil are, like other reservoirs, predominately $\mathrm{CO}_{2}$ supersaturated (Table 2), and in general sources of $\mathrm{CO}_{2}$ to the atmosphere. These $\mathrm{CO}_{2}$ fluxes, however, are considerably smaller than those reported for many reservoirs to date. For example, the mean $\mathrm{CO}_{2}$ fluxes from our study ranged from -2.2 (influx) to an efflux of $108.9 \mathrm{mmol} \mathrm{C} \mathrm{m}^{2}$ day $^{-1}$ $\left(\right.$ mean $=16.50$ and median $=13.9 \mathrm{mmol} \mathrm{C} \mathrm{m}^{2}$ day $\left.^{-1}\right)$ among reservoirs. The mean flux reported by St. Louis et al. (2000) for global hydroelectric reservoirs was $59.8 \mathrm{mmol} \mathrm{C} \mathrm{m}^{2}$ day $^{-1}$. Furthermore, our study shows that residence time (RT):reservoir area ratio (c); $\mathrm{CV}$ on $p \mathrm{CO}_{2}$ Watershed area ratio (d); $\mathrm{CV}$ on $p \mathrm{CO}_{2}$ versus TOC in: watershed area ratio (e). *Significance level $P<0.05$

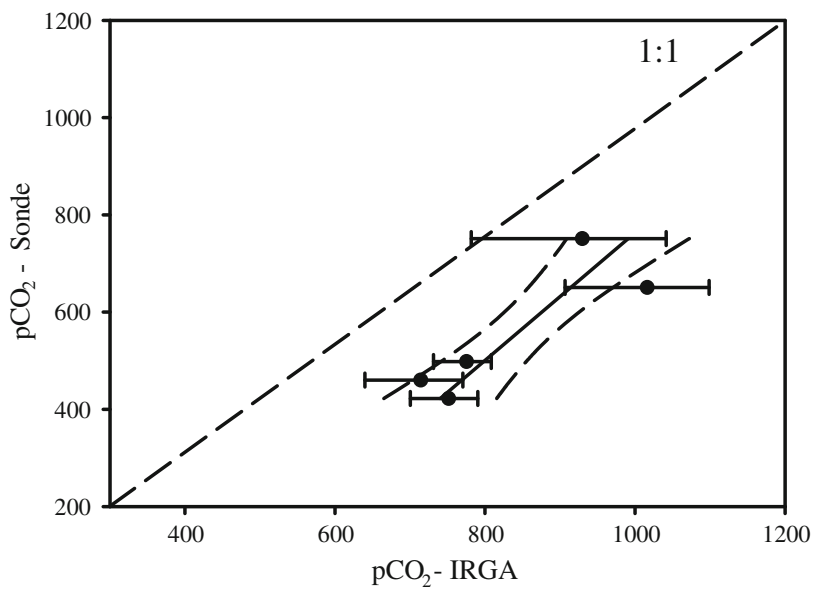

Fig. 7 Relationship between $p \mathrm{CO}_{2}$ ( $\mu$ atm) estimated by sonde $(Y)$ and by IRGA $(X)$. Each value represents mean and standard deviation for each reservoir sampled in time and space (FNS, MSM, LBC, MAN and FUN). The dashed lines represent the $99 \%$ confidence interval. The equation of regression is Sonde $=0.798 \times$ IRGA + $393.45\left(r^{2}=0.73, P=0.0285\right)$

$\mathrm{CO}_{2}$ saturation varies both seasonally and over space in large tropical reservoirs. Kelly et al. (2001) found higher seasonal variation compared to spatial variation and showed that in natural temperate lakes, a single spot should be adequate to determine if a lake is above or below equilibrium with the atmosphere.

Our study found as much more variation over space than between wet and dry seasons, representing the extremes in temporal variability. Had we used only the data near the dam, as in most reservoir studies, as the sole location for the calculation of $p \mathrm{CO}_{2}$, we would have underestimated 
flux by more than $25 \%$, or as much as $32 \%$ in some reservoirs. In our systems, the site closest to the dam tended to have the lowest $p \mathrm{CO}_{2}$ saturation compared to other sites (Fig. 8). We suggest, therefore, that the reservoir systems may need to be re-examined spatially before we can have confidence in flux estimates.

We observed consistent spatial patterns in $p \mathrm{CO}_{2}$ in all the studied reservoirs. For example, the higher elevated $p \mathrm{CO}_{2}$ at some sites in FNS and FUN co-occurred with the locations of significant sewage outfalls (Soares et al. 2008). Further, some reservoirs receive $\mathrm{CO}_{2}$ rich hypolimnetic waters from upstream reservoirs, such as in cascade reservoirs. The main MSM reservoir is located just after the dam of FNS. The higher $p \mathrm{CO}_{2}$ near the dam (in the reservoir) of FNS promoting high downriver degassing in MSM. Similarly, LBC is just downriver of the MSM dam and is similarly influenced by the hypolimnetic water from MSM (Fig. 2). Another factor that likely causes spatial variation in $p \mathrm{CO}_{2}$ is variation in reservoir depth. In the one system for which we have good bathymetric data (MSM), $p \mathrm{CO}_{2}$ was clearly higher in the shallows and lower in the deep regions (Fig. 3c). It is likely that variation in depth contributes to spatial variability in the other systems as well.

Our original hypothesis, that variability would be related to morphometric complexity was not supported. The variability could be partially understood by a combination of morphological and hydrological parameters. Neither the index of shoreline development, nor reservoir area, nor water residence time were significantly correlated, among reservoirs, to variability in $p \mathrm{CO}_{2}$. On the other hand, some parameters (watershed area; the ratio of water residence time to reservoir area) were strongly correlated with this variability (Fig. 5). We do not have a mechanistic explanation for these relationships, and it is probably premature

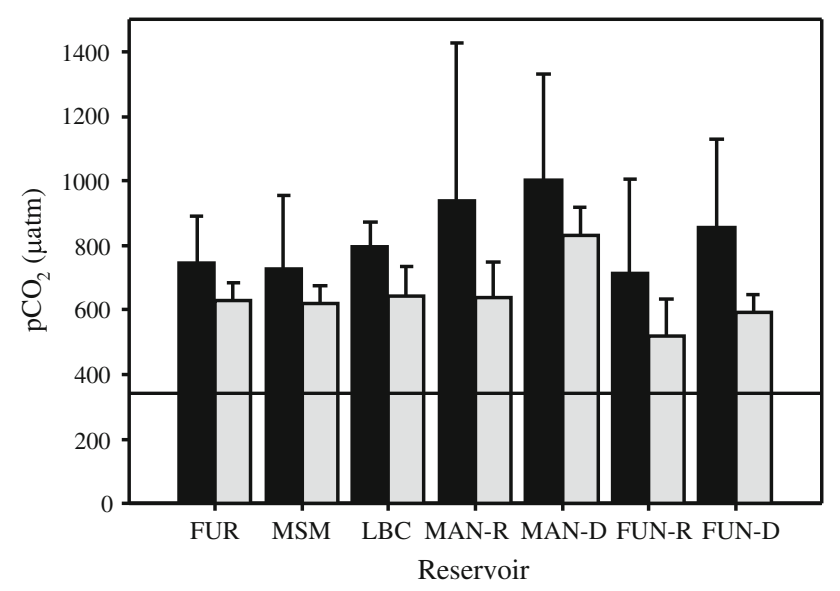

Fig. 8 Comparison, for every hydroelectric reservoir, between $p \mathrm{CO}_{2}$ data (mean and SD) measured in all sites along the reservoir (black bars) and those measured only near the dam (gray bars) to propose a conceptual model based only 5 reservoir systems. Nevertheless, the strong positive correlation between spatial variability and RT:RA is striking in that there is no significant correlation to either RT or RA alone. That the reservoirs with the smallest watersheds, independent of other factors, had the greatest spatial variation is also surprising.

The water level in hydroelectric reservoirs is strongly driven by the operation of the dam, since the turbines must generate power by water fluxes. This procedure sucks water from the reservoir, potentially enhancing spatial variability in $p \mathrm{CO}_{2}$. Moreover, during the intense tropical rainy season, the excess water must be dropped downriver through the spillway. This induced water transportation promotes internal currents that may effect mixing (GalyLacaux et al. 1997). Furthermore, the position of the outlet is a potential in-system driver of patterns in $p \mathrm{CO}_{2}$ distribution. The reservoirs in which the outlet is positioned in the hypolimnetic layer, FUN for example, deep waters highly supersaturated in $p \mathrm{CO}_{2}$ (unpublished data) is pumped downriver removing some or much of this water before water column mixing takes place. A strong inverse correlation between $p \mathrm{CO}_{2}$ and $Z_{\max }$ (maximum depth) was observed in Manso reservoir (Fig. 3c). Regions shallower than $20 \mathrm{~m}$ deep showed a higher variation in $p \mathrm{CO}_{2}$ values $(\mathrm{CV}=0.48)$ when compared to deeper regions $(\mathrm{CV}=0.24)$. The higher and more variable $p \mathrm{CO}_{2}$ values in shallow regions may be related to higher inputs of organic matter; more intense hydrodynamic interferences; variability in benthic metabolism, and a lack of stability of the water column. The higher inputs of organic matter to shallow regions are related to the fact that these are usually riverine or marginal zones, which are more closely connected to the terrestrial environment. Shallow regions are more susceptible to the effects of hydrodynamic interferences. Vertical mixing events, especially if caused by intense winds, for instance, may easily disturb the sediments of shallow regions. While we have only one documented mixing event in our data set (Figs. 3, 4), these events and their legacies might cause some of the observed spatial variability. Finally, the lack of stability of shallow water regions is related to a less frequent stratification, and, thus, to a more frequently mixed system.

Meteorological events like storms and thermal winds play a crucial role in the gas fluxes in reservoir (Abril et al. 2005), promoting a multiplicative effect on the instantaneous atmospheric fluxes. The gas concentration increases at the surface by vertical mixing. We documented an example of this physical process in MAN (Fig. 3a, b).

In summary, the spatial variability in $\mathrm{CO}_{2}$ flux from hydroelectric reservoirs is probably caused by a combination of in-system and external forces. Hydrodynamic events linked to depth and residence time appears to be key 
factors modulating $p \mathrm{CO}_{2}$ spatial patterns. External forces like watershed dimension and input of carbon play combined actions explaining the variability. Our measurements in both spatial and temporal scales show that continuous data at single sites (high temporal frequency data) can provide real estimates in time but may miss zones with high fluxes. For our reservoirs, the continuous time series at the dam sites underestimated $\mathrm{CO}_{2}$ flux by up to $30 \%$ compared to full spatial data. Future reservoirs gas studies should strive to include spatial variation.

Acknowledgments We are grateful to V. L. M. Huszar and D. Abe whose criticisms and insights greatly improved the manuscript. We also thank G. R. Marques for assistance in sample analysis and field work and to Matthew Gillespie (Cary IES) for revising the English. Financial support was provided by FURNAS Centrais Elétricas S.A. and grants from National Council of Research and Development (CNPq) Brazil. This is a contribution to the Laboratory of Aquatic Ecology and Ecology Program of the Federal University of Juiz de Fora.

Open Access This article is distributed under the terms of the Creative Commons Attribution Noncommercial License which permits any noncommercial use, distribution, and reproduction in any medium, provided the original author(s) and source are credited.

\section{References}

Abril G, Guerin F, Richard S, Delmas R, Galy-Lacaux C, Gosse P, Tremblay A, Varfalvy L, Dos Santos MA, Matvienko B (2005) Carbon dioxide and methane emissions and the carbon budget of a 10-year old tropical reservoir (Petit Saut, French Guiana). Global Biogeochem Cycles 19:GB4007. doi:10.1029/2005 GB002457

Akaike HA (1974) New look at statistical model identification. IEEE Trans Autom Control 19(6):716-723

Bailey TC, Gatrell AC (1995) Interactive spatial data analysis. Longman Scientific and Technical, Essex

Bergstrom AK, Algesten G, Sobek S, Tranvik L, Jansson M (2004) Emission of $\mathrm{CO}_{2}$ from hydroelectric reservoirs in northern Sweden. Archiv für Hydrobiol 159:25-42

Bukaveckas PA, Williams JJ, Hendricks SP (2002) Factors regulating autotrophy and heterotrophy in the main channel and an embayment of a large river impoundment. Aquat Ecol 36:355369

Cole JJ, Caraco NF (1998) Atmospheric exchange of carbon dioxide in a low-wind oligotrophic lake measured by the addition of SF6. Limnol Oceanogr 43:647-656

Cole JJ, Caraco NF, Kling GW, Kratz TK (1994) Carbon-dioxide supersaturation in the surface waters of lakes. Science 265:15681570

del Giorgio PA, Cole JJ, Cimbleris A (1997) Respiration rates in bacteria exceed phytoplankton production in unproductive aquatic systems. Nature 385:148-151

Di Siervi MA, Mariazzi AA, Donadelli JL (1995) Bacterioplankton and phytoplankton production in a large Patagonian reservoir (Republica Argentina). Hydrobiologia 297:123-129

Dos Santos MA, Rosa LP, Sikar B, Sikar E, Dos Santos EO (2006) Gross greenhouse gas fluxes from hydro-power reservoir compared to thermo-power plants. Energy Policy 34:481-488
Duarte CM, Prairie YT (2005) Prevalence of heterotrophy and atmospheric $\mathrm{CO}_{2}$ emissions from aquatic ecosystems. Ecosystems 8:862-870

Duchemin É, Lucotte M, Canuel R, Chamberland A (1995) Production of the greenhouse gases $\mathrm{CH}_{4}$ and $\mathrm{CO}_{2}$ by hydroelectric reservoirs of boreal region. Global Biogeochem Cycles 9:529540

Fearnside PM (2004) Greenhouse gas emissions from hydroelectric dams: controversies provide a springboard for rethinking a supposedly 'clean' energy source - an editorial comment. Clim Change 66:1-8

Finlay K, Leavitti PR, Wissel B, Prairie YT (2009) Regulation of spatial and temporal variability of carbon flux in six hard-water lakes of the northern Great Plains. Limnol Oceanogr 54(6): 2553-2564

Galy-Lacaux C, Delmas R, Jambert C (1997) Gaseous emission and oxygen consumption in hydroelectric dams: a case study in French Guyana. Glob Biogeochem Cycles 11(4):471-483

Giles J (2006) Methane quashes green credentials of hydropower. Nature 444:524-525

Granéli W, Lindell M, Tranvik L (1996) Photo-oxidative production of dissolved inorganic carbon in lakes of different humic content. Limnol Oceanogr 41:698-706

Guerin F, Abril G, Richard S, Burban B, Reynouard C, Seyler P, Delmas R (2006) Methane and carbon dioxide emissions from tropical reservoirs: significance of downstream rivers. Geophys Res Lett 33:L21407. doi:10.1029/2006GL027929

Guerin F, Abril G, Serça D, Delon C, Richard S, Delmas R, Tremblay A, Varfaluy L (2007) Gas transfer velocities of $\mathrm{CO}_{2}$ and $\mathrm{CH}_{4}$ in a tropical reservoir and its river downstream. J Mar Syst 66:161172

Herczeg AL, Hesslein RH (1984) Determination of hydrogen ion concentration in softwater lakes using carbon dioxide equilibria. Geochim Cosmochim Acta 48:837-845

Hesslein RH, Rudd JWM, Kelly C, Ramlal P, Hallard A (1991) Carbon dioxide pressure in surface waters of Canadian Lakes. In: Wilhelms SC, Gulliver JS (eds) Air-water mass transfer. American Society of Civil Engineers, Washington, DC, pp 413-431S

Jahne B, Munnich KO, Bosinger R, Dutzi A, Huber W, Libner P (1987) On parameters influencing air-water gas exchange. J Geophys Res 92:1937-1949

Jones CD, Cox PM, Essery RLH, Roberts DL, Woodage MJ (2003) Strong carbon cycle feedbacks in a climate model with interactive $\mathrm{CO}_{2}$ and sulphate aerosols. Geophys Res Lett 30:1479. doi:10.1029/2003GL016867

Jugnia L-B, Dévaux J (2008) Bacterioplankton heterotrophic activity in relation to the phytoplankton compartment in a recently formed reservoir. Lakes Reserv Res Manag 13:13-22

Jugnia L-B, Richardot M, Debroas D, Dévaux J (2006) Bacterial production in the recently flooded Sep Reservoir: diel changes in relation to dissolved carbohydrates and combined amino acids. Hydrobiologia 563:421-430

Kelly CA, Fee E, Ramlal PS, Rudd JWM, Hesslein RH, Anema C, Schindler EU (2001) Natural variability of carbon dioxide and net epilimnetic production in the surface waters of boreal lakes of different sizes. Limnol Oceanogr 46:1054-1064

Kemenes A, Forsberg BR, Melack JM (2007) Methane release below a tropical hydroelectric dam. Geophys Res Lett 34:LI2809

Kling GW, Kipphut GW, Miller MC (1991) Arctic lakes and streams as gas conduits to the atmosphere-implications for tundra carbon budgets. Science 251:298-301

Lauster GH, Hanson PC, Kratz TK (2006) Gross primary production and respiration differences among littoral and pelagic habitats in northern Wisconsin lakes. Can J Fish Aquat Sci 63:1130-1141

Lima IBT (2005) Biogeochemical distinction of methane releases from two Amazon hydroreservoirs. Chemosphere 59:1697-1702 
Lorenzzetti JA, Stech JL, Assireu AT, Novo EMLM, Lima IBT (2005) SIMA: a near real time buoy acquisition and telemetry system as a support for limnological studies. In: Santos MA, Rosa LP (eds) Global warming and hydroelectric reservoirs. COPPE, Rio de Janeiro., pp 71-79

Niemer E (1989) Climatologia do Brasil, 2nd edn. IBGE, 421 pp

Palmer SM, Hope D, Billett MF, Dawson JJC, Bryant CL (2001) Sources of organic and inorganic carbon in a headwater stream: Evidence from carbon isotope studies. Biogeochemistry 52:321-338

Raymond PA, Cole JJ (2003) Increase in the export of alkalinity from North America's largest river. Science 301:88-91

Richardot M, Debroas D, Jugnia L-B, Tadonléké RD, Berthon L, Dévaux J (2000) Changes in bacterial processing and composition of dissolved organic matter in a newly-flooded reservoir (a three-year study). Archiv für Hydrobiologie 148:231-248

Robarts RD, Wicks RJ (1990) Heterotrophic bacterial production and its dependence on autotrophic production in a hypertrophic African reservoir. Can J Fish Aquat Sci 47:1027-1037

Roehm C, Tremblay A (2006) Role of turbines in the carbon dioxide emissions from two boreal reservoirs, Quebec. Can J Geophys Res 111:D24101. doi:10.1029/2006JD007292

Rosa LP, Dos Santos MA, Matvienko B, Dos Santos EO, Sikar E (2004) Greenhouse gas emissions from hydroelectric reservoirs in tropical regions. Clim Change 66:9-21

Rudd JWM, Harris R, Kelly CA, Hecky RE (1993) Are hydroelectric reservoirs significant sources of greenhouse gases? Ambio 22:246-248

Smith SV (1985) Physical, chemical and biological characteristics of $\mathrm{CO}_{2}$ gas flux across the air water interface. Plant Cell Environ $8: 387-398$
Soares MCS, Marinho MM, Huszar VLM, Branco CWC, Azevedo SMFO (2008) The effects of water retention time and watershed features on the limnology of two tropical reservoirs in Brazil. Lakes Reserv Res Manag 13:257-269

Sobek S, Tranvik LJ, Cole JJ (2005) Temperature independence of carbon dioxide supersaturation in global lakes. Global Biogeochem Cycles 19:GB2003. doi:10.1029/2004GB002264

Sobek S, Söderbäck B, Karlsson S, Andersson E, Brunberg AK (2006) A carbon budget of a small humic lake: an example of the importance of lakes for organic matter cycling in boreal catchments. Ambio 35(8):469-475

St. Louis VL, Kelly CA, Duchemin E, Rudd JWM, Rosenberg DM (2000) Reservoir surfaces as sources of greenhouse gases to the atmosphere: A global estimate. Bioscience 50:766-775

Stets EG, Striegl RG, Aiken GR, Rosenberry DO, Winter TC (2009) Hydrologic support of carbon dioxide flux revealed by wholelake carbon budgets. J Geophys Res Biogeosci 114:G01008. doi: 10.1029/2008JG000783

Stumm W, Morgan JJ (1996) Aquatic chemistry: chemical equilibria and rates in natural waters. Wiley, Hoboken

Tremblay A, Lambert M, Gagnon L (2004) Do hydroelectric reservoirs emit greenhouse gases? Environ Manag 33:509-517

Wanninkhof R, Knox M (1996) Chemical enhancement of $\mathrm{CO}_{2}$ exchange in natural waters. Limnol Oceanogr 41:689-697

Weiss RF (1974) Carbon dioxide in water and seawater: the solubility if a non-ideal gas. Mar Chem 2:203-215

Wetzel RG, Likens GE (2000) Limnological analyses, book 3. Springer, New York 